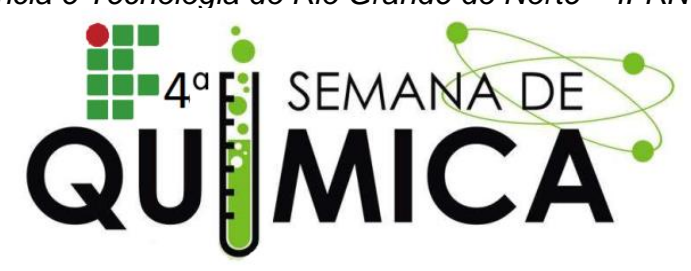

\title{
ANÁLISE FÍSICO-QUÍMICA DE TURBIDEZ DO AÇUDE DOURADO DA CIDADE DE CURRAIS NOVOS
}

*LUCENA, D.P. (IFRN); NASCIMENTO, M.M.T. (IFRN); NETO, N.R. S (IFRN); ANTAS, F.PS(IFRN).

Palavras Chave: Água; Turbidez; Qualidade.

\section{INTRODUÇÃO}

O açude Dourado está localizado na cidade de Currais Novos- RN apresentando capacidade de armazenar 10 milhões de metros cúbicos de água. A pesquisa teve como objetivo o monitoramento do parâmetro de turbidez da água do referente açude.

A turbidez da água é devida à presença de materiais sólidos em suspensão, que reduzem a sua transparência. Pode ser provocada também pela presença de algas, plâncton, matéria orgânica e muitas outras substâncias como o zinco, ferro, manganês e areia, resultantes do processo natural de erosão ou de despejos domésticos e industriais. (Manual prático de análise de água, 2006).

\section{METODOLOGIA}

A coleta de água ocorreu no dia 10 de agosto de 2016, em 3 (três) pontos diferentes do referente açude, que é usado para abastecimento da cidade. Foram usados frascos de polietileno para a coleta. $O$ método utilizado para coleta foi recolher água do açude a 50 centímetros da superfície. Em seguida foi realizada a analise no laboratório do IFRN- Campus Currais Novos.

Coleta 1: Lado esquerdo, onde à presença de pesca e concentração do lixo.

Coleta 2: Lado direito, onde as pessoas utilizam para o lazer.

Coleta 3: Lado norte, onde à presença de lavouras.

\section{RESULTADOS E DISCUSSÕES}

$\mathrm{Na}$ analise da turbidez, foi utilizado o turbidímetro devidamente calibrado. $O$ resultado obtido foi:

\begin{tabular}{|l|l|l|}
\hline Coleta 1 & 3.89 & NTU \\
\hline Coleta 2 & 4.78 & NTU \\
\hline Coleta 3 & 7.54 & NTU \\
\hline
\end{tabular}

Tabela 1: Resultados das coletas.
Considerando que uma água turva pode estar própria para o consumo, contudo uma água turva é um indicador de que essa água esta suja e possivelmente contaminada, de acordo com a Portaria 518/04 do Ministério da Saúde (BRASIL, 2004), a água potável deve estar em conformidade com o padrão de aceitação para consumo humano. Esse estabelece valor máximo permitido para turbidez, um valor de no máximo 5 NTU5.

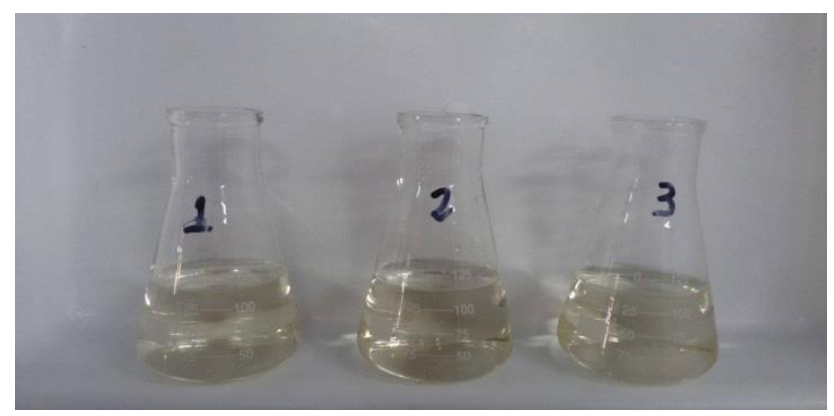

Figura 2: Amostras da coleta de água.

\section{CONCLUSÃO}

De maneira geral a turbidez não será um grande problema no tratamento da água, por isso, a água do açude Dourado mesmo com a sua turbidez um pouco elevada não resulta riscos a população.

\section{REFERÊNCIAS}

Açude Dourado (Currais Novos) Disponível em : http//wikimapia.org/6266427/pt/A\%C3\%A7udeDourado acessado 10/08/16

Turbidez Disponível em:

http://www.ufrrj.br/institutos/it/de/acidentes/turb.htm acessado em 10/08/16

Manual prático de análise de água. $2^{\mathrm{a}}$ ed. rev. Brasília: Fundação Nacional de Saúde, 2006. 